CfR working paper No. 10-19

Market Response to Investor sentiment

J. Hengelbrock • $€$. Theissen •

C. westheide

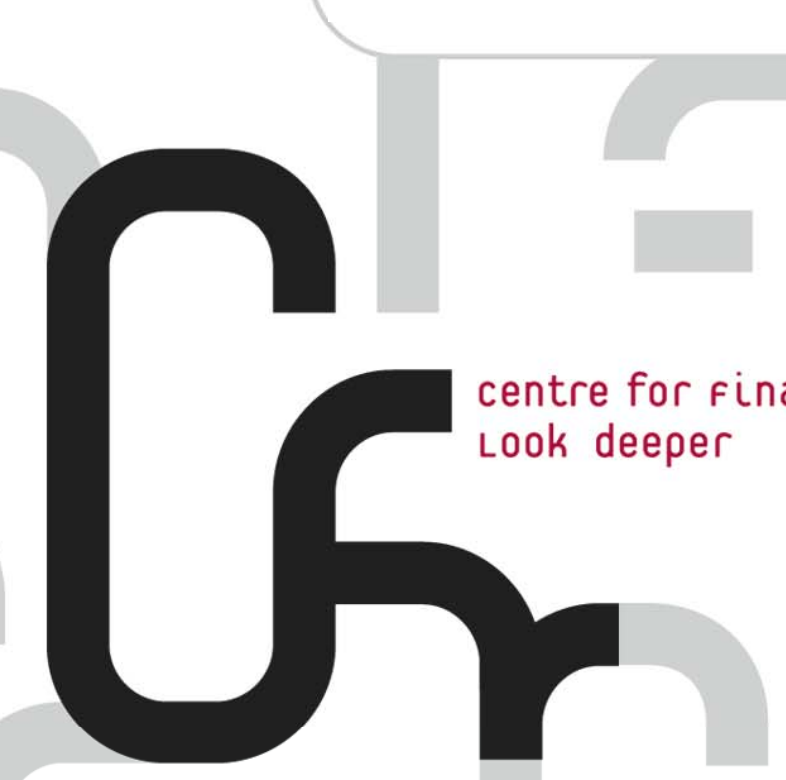




\title{
Market Response to Investor Sentiment
}

\author{
Jördis Hengelbrock Erik Theissen Christian Westheide ${ }^{\dagger}$
}

This version: December 16, 2010

\begin{abstract}
Recent empirical research suggests that measures of investor sentiment have predictive power for future stock returns over the intermediate and long term. Given the widespread publication of sentiment indicators, smart investors should trade on the information conveyed by such indicators and thus trigger an immediate market response to their publication. The present paper is the first to empirically analyze whether an immediate response can be identified from the data. We use survey-based sentiment indicators from two countries (Germany and the US). Consistent with previous research we find there is predictability at intermediate time horizons. For the US, however, the predictability disappears after 1994. Using event study methodology we find that the publication of sentiment indicators affects market returns. The sign of the immediate response is the same as that of the predictability over the intermediate term. This finding is consistent with the idea that sentiment is related to mispricing, but is inconsistent with the idea that the sentiment indicator provides information about future expected returns.
\end{abstract}

Keywords: Investor Sentiment, Event Study, Return Predictability

JEL-Classification: G12, G14

\footnotetext{
${ }^{\dagger}$ Jördis Hengelbrock is from Bonn Graduate School of Economics, University of Bonn, joerdis.hengelbrock@uni-bonn.de. Erik Theissen is from University of Mannheim, theissen@unimannheim.de. Christian Westheide is from Bonn Graduate School of Economics, University of Bonn, christian.westheide@uni-bonn.de. Hengelbrock and Westheide gratefully acknowledge financial support from the German Research Association (DFG). We are grateful to Jörg Breitung, Greg Brown, Mike Cliff, Daniel Dorn and Markus Glaser for helpful conversations.
} 


\section{Introduction}

Recent empirical research suggests that survey measures of investor sentiment have the ability to predict future stock returns over the intermediate and long term. The usual econometric approach is to regress future stock index returns on a sentiment indicator and appropriate control variables. The aim of using the controls is to account for variables (such as the term and yield spread) that are already known to predict future returns. A significant coefficient for the sentiment indicator is interpreted as evidence that sentiment predicts future returns.

There are at least two potential explanations for the predictive ability of sentiment indicators. First, sentiment indices may contain information about future expected returns that is not already captured by the control variables. ${ }^{1}$ In this case, the predictive ability of sentiment indicators does not necessarily imply a violation of market efficiency. Second, sentiment indicators may be related to mispricing (as proposed by Brown and Cliff (2005) and others). In this case, the predictive power of sentiment measures provides evidence for a violation of market efficiency.

The implications of these two alternative explanations differ markedly. It is thus very important to discriminate between the 'expected return news' and 'mispricing' scenarios. The present paper makes a step in this direction. Our approach is to simultaneously consider intermediate and long-horizon predictability on the one hand, and the immediate market reaction to the publication of sentiment indicators on the other. This approach has a simple intuition. Current prices are inversely related to expected returns. If sentiment indicators contain information about future expected returns, the sign of the immediate market reaction should be opposite to that obtained from long-term predictive regressions. If, on the other hand, sentiment indicators are related to mispricing, we should find that the immediate market reaction has the same sign as that found from predictive regressions. This is due to the fact that smart investors exploit the information

\footnotetext{
${ }^{1}$ Alternatively, sentiment indicators could forecast higher expected future cash flows. In this case the publication of the sentiment indicator should trigger an immediate price effect (i.e., a significant announcement day return), but should not predict future returns over longer horizons. The intermediate and long-term predictability reported in previous research is thus inconsistent with this interpretation. Therefore we only consider the "expected return news" explanation and confront it with explanations based on mispricing.
} 
contained in the sentiment indicator. If bullish sentiment predicts positive [negative] future returns smart investors will buy [sell] and thus cause an immediate positive [negative] market reaction. ${ }^{2}$

To the best of our knowledge, our paper is the first to empirically analyze the immediate response of stock returns to the publication of survey-based sentiment measures. We use data from Germany and the US. In the first part of our analysis we rely on the methodology proposed by Brown and Cliff (2005). We replicate their tests for medium and long-term predictability. Consistent with previous results in the literature, we find a significant negative relationship between the sentiment indicator and subsequent medium term (up to three months) index returns in the US for the earlier parts of our sample period (1987-1994 and, to a much lesser extent, 1994-2001). This relationship disappears towards the end of our sample period. In the final subperiod (2001-2008), the coefficients of the predictive regressions are predominantly positive but only weakly significant. The sentiment indicator for the German market is correlated positively with future returns. This is consistent with the results from the US, because the German sample covers he years 2001-2008, which is precisely the period for which we also find positive coefficients in the US sample.

In the second step of our analysis, we use event study methodology to test whether daily index returns respond to the publication of the sentiment indicator. We do find a significant positive announcement day effect in Germany. However, not all of the predictive power of the indicator is captured on the announcement day. This pattern is consistent with a scenario of mispricing and of limited arbitrage. Smart investors are aware of the predictive power of the sentiment indicator and trade accordingly. However, they do not fully arbitrage the predictability away, possibly because of increased noise trader risk (as in the model of De Long et al. (1990)). For the US market there is evidence of a negative publication day effect in the subperiod 1987-1994. As in the case of Germany this result is consistent with a scenario of mispricing and limited arbitrage. In later subperiods there is no such

\footnotetext{
${ }^{2}$ Of course, with perfect arbitrage we would expect to see only an immediate price reaction. The stylized fact that sentiment does predict future returns can thus only be reconciled with mispricing if there are limits to arbitrage.
} 
effect. This should come as no surprise, because the intermediate- to long-term predictability also largely disappears towards the end of the sample period.

Our paper is related to previous studies investigating the predictive power of sentiment indicators. Brown and Cliff (2004, 2005), Clarke and Statman (1998), Fisher and Statman (2000), Kaniel et al. (2008), Otoo (1999), Shiller (2000), Solt and Statman (1988) and Verma et al. (2008) all analyze survey-based sentiment measures for the US market. ${ }^{3}$ Although the results are mixed (probably due to differences in sample periods, methodology, and the forecasting periods), on balance these previous studies find evidence of long-horizon predictability. Schmeling (2007) applies a similar methodology to data from the German stock market and also reports evidence of predictability. Although some papers have tested for shortterm predictability (e.g. at the weekly and monthly level as in Brown and Cliff (2004)), to our knowledge, the present paper is the first to test for announcement day effects. ${ }^{4}$

More generally, our paper also relates to previous research testing for return predictability (see Ang and Bekaert (2007) for a recent contribution). In particular, certain methodological concerns (the problem of using persistent regressors, first addressed by Stambaugh (1999), and the problem of using overlapping return data) are also present in our study. We account for these problems by adopting the bootstrap-based bias correction proposed by Brown and Cliff (2005).

The remainder of this paper is structured as follows. Section 2 describes our data set. In section 3, we present the methodology and results of our tests for predictability. Section 4 describes our tests for the existence of announcement day effects. Section 5 concludes.

\footnotetext{
${ }^{3} \mathrm{~A}$ large number of papers uses market-based sentiment measures. These sentiment proxies include, but are not limited to, mutual fund flows (Brown et al. (2003)), the closed-end fund discount (Elton et al. (1998), Lee et al. (1991), Neal and Wheatley (1998)), put-call ratios (Dennis and Mayhew (2002)) and various measures of trading activity (Barber and Odean (2008), Kumar and Lee (2002, 2006)). Baker and Wurgler (2006) construct a composite sentiment measure based on six underlying proxies. Brown and Cliff (2004) analyze market-based and survey-based sentiment measures and conclude that many of these measures are correlated.

${ }^{4}$ Schmitz et al. (2009) document short-term predictability (one and two days) of a sentiment measure constructed from data on warrant trades of retail investors. The data used to construct this measure is, however, not publicly available.
} 


\section{Data}

\subsection{German Data}

The analysis of intermediate and long-term predictability is based on weekly data. We use survey data from Sentix as our measure of investor sentiment. We prefer to use survey-based sentiment indicators over market-based ones because the publication of the survey results constitutes new information, while market-based indicators often only aggregate information that were already available.

Sentix conducts weekly surveys of institutional and private investors, and currently reaches over 2700 registered participants, about 800 of whom take part in the survey each week. Individual investors constitute on average about $76 \%$ of respondents, with this percentage generally varying between $70 \%$ and $80 \%$. Voting is possible between Thursday afternoon and Saturday. Participants are asked whether they are bullish, bearish, neutral, or have no opinion with regard to the future trend of the DAX30 stock index over the following one and six months, respectively. In our analysis we only use data for the six month horizon because the AAII survey that we use in our US sample is also based on a six months forecasting horizon.

From the individual opinions obtained, Sentix computes the so-called value index, also known as the bull-bear spread. This is defined as

$$
S_{t}=\frac{\# \text { bullish }-\# \text { bearish }}{\# \text { total }}
$$

The Sentix index is published every Sunday evening or Monday morning prior to the opening of the market. It is available to all participants, and additionally, since January 2004, it has been available trough Thomson DataStream and Bloomberg. Furthermore, subindices that cover individual and institutional investors, respectively, are made available exclusively to participants.

The Sentix data starts on February 26, 2001 and ends on June 30, 2008. For our predictive regressions, we use forecasting horizons of 1, 4, 8, 13 and 26 weeks. To this end, we combine the Sentix data with data on the DAX index for the period February 26, 2001 to December 31, 2008. The aim of the predictive regressions is 
to test whether the sentiment indicator contains information about future returns beyond the information inferable from other publicly observable variables. We therefore control for variables that are known to predict future market returns. We include the return on the DAX30 for the previous week, the exchange rate EUR/USD, the interest rate term spread between 10 year German government bonds and the Euribor 3 month rate, the credit spread (defined as the spread between yields on A rated corporate bonds of maturities between 3 and 5 years and the mean of 3 and 5 year German government bond yields ${ }^{5}$ ), the liquidity spread (defined as the spread between the Euribor 3-month and 1-month rates), and the Euribor 1-month rate.

For the analysis of announcement day effects of the Sentix index, i.e. the test whether the publication of the sentiment indicator has an immediate price effect, we use daily data. As the Sentix index is published on the weekend, we consider the return of the DAX30 between its closing value on Friday and that on Monday. To this end, we regress daily DAX returns on a variable which is equal to the sentiment indicator on Mondays and zero on all other days. The regression includes lagged DAX returns, lagged S\&P 500 returns (to account for the fact that respondents may participate in the survey until Saturday and may therefore base their opinion on the US stock market return from the previous week) and a Monday dummy (to control for a weekend effect) as control variables.

Table 1 provides summary statistics of all the variables. The mean of the Sentix index is 0.12 , indicating that the respondents are, on average, slightly bullish. The mean daily DAX return is very close to zero. The serial and cross correlations (shown in the last two columns of the table) indicate that the Sentix index is highly autocorrelated and depends on the previous values of the DAX index. Both these observations are consistent with the findings of previous research.

[Table 1 about here.]

\footnotetext{
${ }^{5}$ The number of corporate bonds issued by German firms and rated Aaa and Baa is to small to reliably estimate the credit spread as the difference between the yields on Baa-rated and Aaa-rated corporate bonds (as we do in our US sample). Therefore, we use the yield difference between A-rated corporate bonds and government bonds instead.
} 


\subsection{US Data}

We use data obtained from the American Association of Individual Investors (AAII). The AAII conducts weekly surveys of its members, the results of which are published every Thursday ${ }^{6}$ morning, before the stock market opens. Participants are asked whether they expect the direction of the stock market over the following six months to be 'up', 'no change', or 'down', and can participate once during every weekly period ranging from Thursday to Wednesday. We use a value index (bull-bear spread) that is calculated using these data. Our sample covers more than 20 years. It starts on July 24, 1987 and extends until June 26, 2008. As Table 2 shows, the mean, standard deviation and first order autocorrelation of the AAII indicator are comparable to those of the German Sentix index. ${ }^{7}$

[Table 2 about here.]

The AAII survey does not specify which stock index it refers to. We therefore use the Dow Jones Industrial Average, the Standard \& Poors 500, the NASDAQ 100, and the Russell 3000 indices. We estimate predictive regressions for forecasting horizons of 1, 4, 8, 13 and 26 weeks. As for the German case, we include other variables known to have predictive power for market returns as control variables. We include the same variables as for the German sample but replace the Euribor rates with Treasury bill rates. Thus, we control for the past week's return of the stock index in question, the exchange rate EUR/USD (DM/USD prior to the introduction of the Euro), the interest rate term spread between 10 year US Treasury bonds and the Treasury bill 3 month rate, the credit spread (defined as the yield spread between Baa and Aaa rated corporate bonds), the liquidity spread

\footnotetext{
${ }^{6}$ This applies to the period from November 1993 onwards. Before, the day of publication had been Friday. In case of public holidays, the index is published on the last trading day before that holiday. In our analysis, we take account of the exact publication days.

${ }^{7}$ Note that while the AAII index published on Thursday morning is more strongly related to the S\&P return over the previous week (ending on the Wednesday prior to publication) in comparison to the German data, the relation is significant only for the later part of our sample. This is most likely due to the fact that, until 2000, the AAII survey was conducted by regular mail. This procedure obviously introduces a lag of several days. We find strong support for this conjecture when we estimate the correlation between the AAII index and the S\&P return over the previous week separately for the period before and after the change in procedure. Prior to 2000 the correlation is 0.010 whereas after 2000 it is 0.287 .
} 
(defined as the spread between the US Treasury bill 3 month and 1 month rates) and the US Treasury bill 1 month rate.

In the analysis of announcement day returns, we again use daily data. We regress daily index returns on a variable which is equal to the sentiment indicator on Thursdays and zero on all other days. The regression includes lagged index returns and a Monday dummy (to control for a weekend effect) as control variables.

\section{Predictive Regressions}

\subsection{Results for Germany}

In this section we analyze whether investor sentiment, measured using the Sentix survey, is able to predict asset returns for horizons from one to 26 weeks. As proposed by Brown and Cliff (2005), we use a bootstrap simulation to account for problems caused by overlapping observations and persistent regressors. ${ }^{8}$ We estimate

$$
\left(r_{t+1}+\ldots+r_{t+k}\right)=\alpha(k)+\Theta^{\prime}(k) z_{t}+\beta(k) S_{t}+\epsilon_{t}^{(k)},
$$

where $r_{t+k}$ denotes the $k$ week-ahead future DAX log return. $\alpha(k)$ is the constant for a forecasting horizon of $k$ weeks, and $z_{t}$ is a vector of the control variables listed in section 2.1. $S_{t}$ is the value of the long-term Sentix survey. Using the bootstrap procedure, we obtain coefficient estimates and associated p-values based on the distribution of the estimated coefficients. Details of the procedure are explained in the Appendix.

Table 3 shows the results obtained using the procedure described above. It shows that the aggregate Sentix index, which, on average, consists of roughly three quarters individual and one quarter institutional respondents, has predictive power for future DAX 30 returns for periods from one to 8 weeks. The bootstrap coefficient estimates are always larger than the OLS estimates, although the differences are small. In spite of their larger numerical values, the bootstrap coefficients have

\footnotetext{
${ }^{8}$ Compare also Brown and Cliff (2005), p. 418.
} 
higher p-values. Our interpretation of the results will be based on the more conservative bootstrap procedure.

[Table 3 about here.]

The sign of the relationship between the sentiment indicator and future DAX returns is positive. From the standard deviation of the Sentix index shown in Table 1 and the coefficient of the predictive regression shown in Table 3, it follows that a change of one standard deviation in the Sentix index is associated with a change in the DAX of almost $2 \%$. over an 8 -week horizon. This is not only statistically, but also economically significant.

These results could indicate that the sentiment index foreshadows future misvaluation. Interestingly, the coefficient in the 26-week predictive regression is the smallest of all the five predictive regressions. This pattern is consistent with the sentiment index indicating a future misvaluation which is subsequently corrected in the second half of the 26 -week prediction period. Alternatively, the sentiment indicator may contain information on future expected returns. The analysis of the announcement day effects in section 4.1 will allow us to discriminate between these interpretations. As previously noted, if the sentiment indicator contains information about future expected returns, the announcement day effect should have a sign opposite to that in the predictive regressions.

\subsection{Results for the US}

We conduct the same analysis as for the Sentix data for the American Association of Individual Investors sentiment index. We use the Standard \& Poors 500 index as the index whose return is to be predicted. However, the results are qualitatively identical for the Dow Jones Industrial Average, the NASDAQ 100, and the Russell 3000 indices. First, we apply our procedure to the whole period from 1987 to 2008. The results, shown in Table 4, indicate that US individual investor sentiment is inversely related to future S\&P 500 returns. Using the bootstrap results, this relation is significant only for the 26 -week ahead forecast. These findings are consistent with those of Fisher and Statman (2000) and Brown and Cliff (2005). These 
authors also find an inverse relationship between sentiment and future returns for samples covering the periods 1987-1998 and 1963-2000, respectively. Our negative coefficient is consistent with the sentiment index indicating a current misvaluation which is subsequently corrected over the forecasting period.

The record of the AAII sentiment index is much longer than that of the Sentix index. In order to check whether the results are stable over time we split the AAII data into three subperiods of approximately equal length and apply our bootstrap procedure to each of these subsamples. The third subsample coincides with the same period as our German sample. Table 5 shows that the negative relationship between the AAII index and subsequent returns disappears over time. It is very pronounced and highly significant in the 1987-1994 sample. In the 1994-2001 sample the coefficients retain their sign but are smaller in magnitude and (at least when considering the bootstrap results) mostly insignificant. In the final subperiod, most coefficient estimates are positive, and the coefficients for the one- and four-week horizons are significant at the 10 percent level. In this subperiod, then, the results for the US are qualitatively similar to those obtained for the German case documented in Table 3. We also found coefficients that were unanimously positive and significant for short forecasting horizons in that case. We can only speculate about the reasons for the change in the predictive ability of the AAII index over time. One possible explanation is the change in the way the AAII survey is conducted. Originally, the votes were collected by post which resulted in a lag of some days. This lag ceased when AAII began to collect the votes via the internet in 2000. The change in the procedure may also have affected the composition of the subgroup of AAII members that respond to the survey. Finally, it is conceivable that the characteristics of the AAII members themselves have changed over time.

As noted above, for the period 2001 - 2008 we find positive coefficients in the predictive regressions both for Germany and the US. Although the signs of the coefficients are similar for the two countries, their magnitude is not. Consider the 8-week forecasting period as an example. As noted in the previous section a change of one standard deviation in the Sentix index is associated with a $2 \%$ 
change in the DAX over an 8-week horizon. The corresponding figure for the US is less than $0.5 \%$. It thus appears that the predictive power of the Sentix index is stronger than that of the AAII index. This may be due to differences in the populations of the respective participants. The Sentix index is much younger than the AAII survey and is much less well known to the general public. Participants in the Sentix survey are likely to be active traders with a strong interest in financial markets. This may not be generally true for respondents to the AAII survey. ${ }^{9}$

[Table 4 about here.]

[Table 5 about here.]

\section{Announcement Day Effects}

\subsection{Results for Germany}

Having established that the German investor sentiment survey Sentix is indeed able to predict the future movements in the DAX index, we now test whether the market reacts to the publication of the sentiment indicator. To this end, we regress daily DAX log returns $r_{t-1, t}^{D A X}$ on their first $\operatorname{lag}^{10}$ and on the variable Sentiment $t_{t}$ which captures the information content of the sentiment indicator. Because the Sentix index is published on Sunday evenings or on Monday mornings prior to the

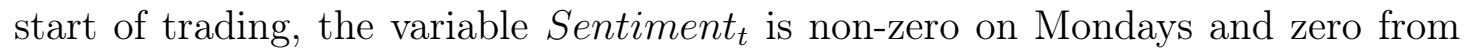
Tuesdays to Fridays.

Respondents to the German survey can submit their statement after observing the closing prices on the US stock market. We therefore include the lagged log

\footnotetext{
${ }^{9}$ To shed more light on the differences between the Sentix and AAII indices we related them to the time series of flows into mutual funds (results are omitted from the paper). The results indicate that the AAII index is highly positively correlated to net flows into equity funds while there is no significant relation for the Sentix index.

${ }^{10}$ The DAX index is calculated from the prices in Xetra, the by far most liquid market for German stocks. Until November 2003 trading in Xetra closed at 8 p.m. Since then, however, trading in Xetra closes at 5.30 p.m. while trading on the floor of the Frankfurt Stock Exchange (which coexists with Xetra) continues until 8 p.m. When survey respondents submit their opinion during the week end they know the prices from floor trading. Therefore, from November 2003 onwards, the lagged DAX return included on the right-hand side is the return of an index called Late DAX. It is based on the same formula and weighting scheme as the DAX but uses the prices from the floor of the Frankfurt Stock Exchange.
} 
returns of the S\&P 500 index, $r_{t-2, t-1}^{S \& P 500}$ in our regression. ${ }^{11}$ Finally, we include a Monday dummy $\mathbf{1}_{\text {Mondayt }}$ in order to capture possible day-of-the-week effects. For daily returns, problems induced by serial correlation are not an issue. However, the pattern of OLS residuals indicates strong ARCH effects, for which we account by specifying a $\operatorname{GARCH}(1,1)$ model. We estimate the following equations ${ }^{12}$ :

$$
\begin{aligned}
r_{t-1, t}^{D A X} & =a_{0}+a_{1} \text { Sentiment }_{t}+a_{2} r_{t-2, t-1}^{D A X}+a_{3} r_{t-2, t-1}^{S \& P 500}+a_{4} \mathbf{1}_{\text {Monday }_{t}}+e_{t} \\
\sigma_{t}^{2} & =b_{0}+b_{1} e_{t-1}^{2}+b_{2} \sigma_{t-1}^{2} .
\end{aligned}
$$

We estimate three specifications. In the first, sentiment is measured as the level of the Sentix value index. The second specification includes the change in the value index rather than its level. The third specification only uses the unexpected change in the value index. We obtain the unexpected change by first regressing the sentiment index on its own lagged values and lagged DAX and S\&P 500 returns and then using the residuals from this regression This procedure is implemented using expanding windows. Thus, the first-pass regression used to identify the unexpected component of the sentiment index only uses information available at time (t-1). ${ }^{13}$ Results are presented in table 6.

[Table 6 about here.]

We find a positive and significant announcement day effect irrespective of the specification used. Thus, all three sentiment variables are significantly positively correlated to daily closing log returns. Hence, the market appears to react to the publication of the investor sentiment index. The DAX increases after a rise and decreases after a fall in the sentiment indicator. Lagged index returns are also

\footnotetext{
${ }^{11}$ If we omitted the lagged S\&P500 returns, the sentiment indicator could be significant merely due to the possibility that it serves as a proxy for the US stock returns after the close of trading in Germany.

${ }^{12}$ As mentioned previously the Sentix index is published on Sunday evening or Monday morning prior to the opening of the market (time index $\mathrm{t}$ ). We analyze whether the publication of the Sentix index affects the DAX return from Friday's close (time t-1) to Monday's close (t).

${ }^{13}$ We use the data for 2001 to initialize the procedure. The first observations included in the second-pass regression are those for January 2002. Therefore, the number of observations in model 3 is lower than in models 1 and 2 .
} 
significant, while we find no clear evidence in favor of a Monday effect on the German stock market.

The announcement day effect is positive and thus has the same sign as the intermediateterm predictability documented in section 3.1. This finding is inconsistent with the idea that the sentiment indicator provides information about future expected returns. If it did, we would expect the announcement day effect to have the opposite sign to that found in the predictive regressions for the intermediate term. Our results thus support a misvaluation interpretation of the predictive power of sentiment indicators.

\subsection{Results for the US}

We conduct a similar analysis to that described above for the AAII sentiment survey. ${ }^{14}$ Remember from section 3.2 that we found negative, but mostly insignificant coefficients in the predictive regressions over the full sample period. Consistent with this result, the first panel of table 7 shows that, for the whole period, there is no significant announcement effect on the day the AAII sentiment is published. By considering the three sub-samples, we find results that mirror those of the predictive regressions shown in table 5. The publication of the sentiment index triggers a negative announcement day effect in the first subsample. The respective coefficient is significant (at the $10 \%$ level or better) in two out of the three specifications. We do not find a significant announcement day effect for the later subsamples. This is not surprising because the predictive regressions presented earlier led to the conclusion that the AAII index is largely unrelated to future returns in these subperiods.

The announcement day effect in the first sub-period has the same sign as that of the coefficients in the predictive regressions. The results for the US, like those for Germany, are thus inconsistent with the expected return news scenario. Rather, they support the interpretation that investor sentiment is related to misvaluation.

[Table 7 about here.]

\footnotetext{
${ }^{14}$ Model 3 again uses a expanding-window procedure. The first year of data (July 1987 - June 1988 ) is used to initialize the procedure, the analysis of the announcement day effects starts in July 1988.
} 


\section{Conclusion}

If sentiment indicators predict future stock market returns over the intermediate and long term (as is suggested by previous empirical research), smart traders can be expected to exploit the information conveyed by the indicator and thus trigger an immediate market response to the publication of the sentiment indicator. The sign of the immediate price reaction will then be the same as that of the intermediate and long-term predictability. If, on the other hand, sentiment indicators provide new information about future expected returns, the sign of the immediate price reaction will be opposite to that of the intermediate and long-term predictability. The present paper is the first to empirically analyze whether an immediate market reaction can be identified in the data, and whether the sign of such a reaction corresponds to the sign of the intermediate and long-term predictive ability. In order to investigate these matters, we use survey-based sentiment indicators from the US (the AAII sentiment index) and for Germany (the Sentix index). In a first step, we replicate earlier results showing that the sentiment indicators do indeed have predictive power for future stock market returns over the intermediate term. We further document that the predictive power of the AAII index has largely disappeared in recent years.

In the second step of our analysis, we use event study methodology to test whether the daily index returns respond to the publication of the sentiment indicator. We do find a significant positive announcement day effect in Germany. This pattern is consistent with mispricing and limited arbitrage. Smart investors are aware of the predictive power of the sentiment indicator and trade accordingly. However, they do not fully arbitrage the predictability away, possibly because of increased noise trader risk (as in the model of de Long et al. (1990)). For the US market, there is evidence of a negative publication day effect in the subperiod 1987-1994. As for the German case, this result is consistent with the mispricing scenario and limited arbitrage. In later subperiods, there is no significant publication day effect. This is unsurprising, because the intermediate to long-term predictability also disappears towards the end of the sample period.

Notwithstanding the differences between the results for Germany and the US , the 
results for the two countries share one characteristic. They are both consistent with a mispricing interpretation of the predictive power of sentiment and inconsistent with the hypothesis that the sentiment indicator contains information about future expected returns.

\section{Appendix}

Similar to Brown and Cliff (2005), we regress future $k$-week returns on the current value of the sentiment index and control variables

$$
\left(r_{t+1}+\ldots+r_{t+k}\right)=\alpha(k)+\Theta^{\prime}(k) z_{t}+\beta(k) S_{t}+\epsilon_{t}^{(k)},
$$

where the variables are defined as in section 3.1. The fact that we use overlapping observations for the regressand induces an $M A(k-1)$ structure in the error terms under the null hypothesis that $\epsilon^{(1)}$ is serially uncorrelated. Since robust standard errors, suggested by Hansen and Hodrick (1980), are known to perform poorly in small samples and the existence of persistent regressors leads to a bias in the coefficient estimates, we opt for a simulation approach to account for the bias and to obtain appropriate critical values for inference.

We replicate the bootstrap simulation of Brown and Cliff (2005), pp. 437, and start by estimating a $\operatorname{VAR}(1)$ model for $y_{t}=\left[r_{t} S_{t} z_{t}^{\prime}\right]$. After the estimation, we impose the null hypothesis that the Sentix sentiment survey does not predict 1week returns, by setting the appropriate element in the coefficient vector of the return equation equal to zero. We then adjust the constant in the constrained model by adding the contribution of average sentiment to the returns obtained by multiplying the original slope value of the sentiment by the average sentiment level to the constant of the return equation. We bootstrap the residuals from the calibration estimates to account for heteroscedasticity, and generate and discard 100 additional observations to delete possible starting effects. In each of the replications, a number equal to our original sample of simulated observations is used to estimate our equation of interest for horizons from one to 26 weeks. Analogous to Brown and Cliff, we repeat the procedure 10,000 times in order to obtain a 
distribution of the values of $\hat{\beta}(k)$.

In order to gauge the statistical significance of the coefficient estimates we compare the sentiment coefficient of the original model with the simulated probability distribution in order to obtain p-values. Because these p-values are based on the actual distribution of the residuals, they are robust to deviations from the normal distribution. 


\section{References}

Ang, A. and G. Bekaert (2007). Stock Return Predictability: Is it There? Review of Financial Studies 20(3), 651-707.

Baker, M. and J. Wurgler (2006). Investor Sentiment and the Cross-Section of Stock Returns. The Journal of Finance 61(4), 1645-1680.

Barber, B. and T. Odean (2008). All That Glitters: The Effect of Attention and News on the Buying Behavior of Individual and Institutional Investors. Review of Financial Studies 21(2), 785-818.

Brown, G. W. and M. T. Cliff (2004). Investor sentiment and the near-term stock market. Journal of Empirical Finance 11, 1-27.

Brown, G. W. and M. T. Cliff (2005). Investor sentiment and asset valuation. Journal of Business 78(2), 405-440.

Brown, S., W. Goetzmann, T. Hiraki, N. Shirishi, and M. Watanabe (2003). Investor sentiment in japanese and us daily mutual fund flows. NBER Working Paper No. W9470.

Clarke, R. and M. Statman (1998). Bullish or Bearish? Financial Analysts Journal 54(3), 63-72.

De Long, J. B., A. Shleifer, L. H. Summers, and R. J. Waldmann (1990). Noise trader risk in financial markets. Journal of Political Economy 98(4), 703-738.

Dennis, P. and S. Mayhew (2002). Risk-Neutral Skewness: Evidence from Stock Options. Journal of Financial and Quantitative Analysis 37(3), 471-493.

Elton, E. J., M. J. Gruber, and J. A. Busse (1998). Do investors care about sentiment? Journal of Business 71(4), 477-500.

Fisher, K. and M. Statman (2000). Investor Sentiment and Stock Returns. Financial Analysts Journal 56(2), 16-23. 
Hansen, L. and R. Hodrick (1980). Forward exchange rates as optimal predictors of future spot rates: An econometric analysis. The Journal of Political Economy 88(5), 829.

Kaniel, R., G. Saar, and S. Titman (2008). Individual Investor Sentiment and Stock Returns. Journal of Finance 63(1), 273-310.

Kumar, A. and C. Lee (2002). Individual Investor Sentiment and Comovement in Small Stock Returns.

Kumar, A. and C. Lee (2006). Retail Investor Sentiment and Return Comovements. The Journal of Finance 61(5), 2451-2486.

Lee, C. M. C., A. Shleifer, and R. H. Thaler (1991). Investor sentiment and the closed-end fund puzzle. Journal of Finance 46(1), 75-109.

Neal, R. and S. M. Wheatley (1998). Do measures of investor sentiment predict returns? Journal of Financial and Quantitative Analysis 33(4), 523-547.

Otoo, M. (1999). Consumer sentiment and the stock market. FEDS Working Paper No. 99-60.

Schmeling, M. (2007). Institutional and individual sentiment: Smart money and noise trader risk? International Journal of Forecasting 23(1), 127-145.

Schmitz, P., M. Glaser, and M. Weber (2009). Individual Investor Sentiment and Stock Returns-What Do We Learn from Warrant Traders? Working Paper.

Shiller, R. (2000). Measuring Bubble Expectations and Investor Confidence. The Journal of Psychology and Financial Markets 1(1), 49-60.

Solt, M. and M. Statman (1988). How useful is the sentiment index? Financial Analysts Journal 44(5), 45-55.

Stambaugh, R. (1999). Predictive regressions. Journal of Financial Economics $54(3), 375-421$. 
Verma, R., H. Baklaci, and G. Soydemi (2008). The impact of rational and irrational sentiments of individual and institutional investors on DJIA and S\&P500 index returns. Applied Financial Economics 18(16), 1303-1317. 


\section{Tables}

Table 1: Summary Statistics of German data

\begin{tabular}{|c|c|c|c|c|}
\hline & Mean & Std. Dev. & $\rho_{i}$ & $\rho_{s, i}$ \\
\hline $\operatorname{Sentix}_{t}$ & 0.121 & 0.113 & 0.773 & 1.000 \\
\hline$\Delta$ Sentix $_{t}$ & -0.000 & 0.067 & -0.301 & 0.335 \\
\hline InnoSentix $_{t}$ & 0.002 & 0.058 & 0.070 & 0.726 \\
\hline$r_{t-2, t-1}^{D A X}$ & 0.000 & 0.032 & 0.016 & 0.048 \\
\hline$r_{t-2, t-1}^{S \& P 500}$ & 0.000 & 0.022 & -0.054 & 0.007 \\
\hline $\mathrm{EUR} / \mathrm{USD}_{t-1}$ & 1.185 & 0.187 & 0.988 & 0.029 \\
\hline 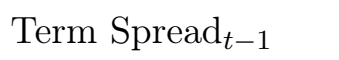 & 0.011 & 0.008 & 0.986 & -0.107 \\
\hline Credit $_{\text {Spread }_{t-1}}$ & 0.011 & 0.003 & 0.946 & -0.243 \\
\hline 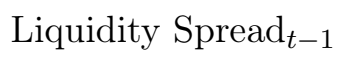 & 0.001 & 0.001 & 0.937 & 0.112 \\
\hline Euribor $1 \mathrm{~m}_{t-1}$ & 0.031 & 0.009 & 0.990 & -0.025 \\
\hline
\end{tabular}

The table presents summary statistics for the German data. All returns are from Friday close to the next Friday close. Other control variables (the EUR/USD exchange rate, the term, credit and liquidity spread and the Euribor 1-month rate) are from Friday. The Sentix index is published on Sunday evenings or Monday mornings. Sentix denotes the index level, $\Delta$ Sentix $_{t}$ denotes its weekly change, and InnoSentix $x_{t}$ the unexpected component of the index (the residual of a linear regression of the index on its lagged value and the lagged DAX return). $\rho_{i}$ denotes the first-order serial correlation of variable $i, \rho_{s, i}$ denotes the correlation between the Sentix index and variable $i$. 
Table 2: Summary Statistics of US data

\begin{tabular}{l|rrrr}
\hline \hline & Mean & Std. Dev. & $\rho_{i}$ & $\rho_{s, i}$ \\
\hline \hline AAII $_{t}$ & 0.099 & 0.188 & 0.670 & 1.000 \\
$\Delta$ AAII $_{t}$ & -0.001 & 0.152 & -0.343 & 0.400 \\
InnoAAII $_{t} \& P 500$ & 0.008 & 0.135 & -0.144 & 0.738 \\
$r_{t-2, t-1}$ & 0.001 & 0.021 & -0.053 & 0.134 \\
USD $/$ EUR $_{t-1}$ & 1.168 & 0.149 & 0.990 & -0.198 \\
Term Spread & 0.017 & 0.012 & 0.992 & 0.026 \\
Credit Spread & 0.009 & 0.002 & 0.979 & -0.202 \\
Liquidity Spread $_{t-1}$ & 0.027 & 0.012 & 0.989 & -0.132 \\
${\text { Treasury bill } 1 \mathrm{~m}_{t-1}}^{\text {Treasur }}$ & 0.017 & 0.008 & 0.988 & -0.152 \\
\hline \hline
\end{tabular}

The table presents summary statistics for the US data. All returns are for the week prior to the publication of the AAII index. Other control variables (the USD/EUR exchange rate, the term, credit and liquidity spread and the 1-month T-bill rate) are from Wednesdays. The AAII index is published on Thursday morning. AAII $_{t}$ denotes the index level, $\Delta \mathrm{AAII}_{t}$ denotes its weekly change, and $\mathrm{InnoAAII}_{t}$ the unexpected component of the index (the residual of a regression of the index on its lagged value and the lagged $\mathrm{S} \& \mathrm{P}$ return). $\rho_{i}$ denotes the first-order serial correlation of variable $i, \rho_{s, i}$ denotes the correlation between the AAII index and variable $i$. 
Table 3: Sentiment Coefficient in $k$-Week Regressions for Aggregate 6 Month DAX Sentiment

\begin{tabular}{llclc}
\hline \hline \multirow{2}{*}{ Reg. Horizon } & \multicolumn{2}{c}{ OLS } & \multicolumn{2}{c}{ Bootstrap } \\
& $\hat{\beta}^{O L S}$ & Sig. level & $\tilde{\beta}^{S I M}$ & Sig. level \\
\hline 1 week & $0.0395^{* *}$ & 0.011 & $0.0403^{* *}$ & 0.036 \\
4 weeks & $0.1101^{* * *}$ & 0.000 & $0.1156^{* *}$ & 0.049 \\
8 weeks & $0.1783^{* * *}$ & 0.000 & $0.1887^{* *}$ & 0.041 \\
13 weeks & $0.1337^{* * *}$ & 0.000 & 0.1519 & 0.194 \\
26 weeks & -0.0455 & 0.712 & -0.0179 & 0.958 \\
\hline \hline
\end{tabular}

The table presents the $\beta$ coefficients of equation $\left(r_{t+1}+\ldots+r_{t+k}\right)=\alpha(k)+\Theta^{\prime}(k) z_{t}+$ $\beta(k) S_{t}+\epsilon_{t}^{(k)}$ obtained from OLS estimation (columns 1 and 2) and bootstrap simulations as explained in the appendix (columns 3 and 4). Results are presented for forecasting horizons of $k=1,4,8,13,26$ weeks. The control variables are listed in section 2.1. ***, $* *$ and $*$ denote statistical significance at the $1 \%, 5 \%$ and $10 \%$ levels, respectively. 
Table 4: Sentiment Coefficient in $k$-Week Regressions for AAII Sentiment and S\&P 500

\begin{tabular}{llclc}
\hline \hline \multirow{2}{*}{ Reg. Horizon } & \multicolumn{2}{c}{ OLS } & \multicolumn{2}{c}{ Bootstrap } \\
& $\hat{\beta}^{\text {OLS }}$ & Sig. level & $\tilde{\beta}^{\text {SIM }}$ & Sig. level \\
\hline 1 week & 0.0024 & 0.810 & 0.0029 & 0.371 \\
4 weeks & $-0.0159^{* * *}$ & 0.002 & -0.0142 & 0.264 \\
8 weeks & $-0.0252^{* * *}$ & 0.000 & -0.0223 & 0.273 \\
13 weeks & $-0.0433^{* * *}$ & 0.000 & -0.0389 & 0.129 \\
26 weeks & $-0.0729^{* * *}$ & 0.000 & $-0.0651^{*}$ & 0.076 \\
\hline \hline
\end{tabular}

The table presents the $\beta$ coefficients of equation $\left(r_{t+1}+\ldots+r_{t+k}\right)=\alpha(k)+\Theta^{\prime}(k) z_{t}+$ $\beta(k) S_{t}+\epsilon_{t}^{(k)}$ obtained from OLS estimation (columns 1 and 2) and bootstrap simulations as explained in the Appendix (columns 3 and 4). Results are presented for periods of $k=1,4,8,13,26$ weeks. The control variables are listed in section 2.2 . ***, ** and * denote statistical significance at the $1 \%, 5 \%$ and $10 \%$ levels, respectively. 
Table 5: Sentiment Coefficient in $k$-Week Regressions for AAII Sentiment and S\&P 500 - Subperiods

\begin{tabular}{|c|c|c|c|c|}
\hline \multicolumn{5}{|c|}{$07 / 1987$ to $06 / 1994$} \\
\hline \multirow[t]{2}{*}{ Reg. Horizon } & \multicolumn{2}{|c|}{ OLS } & \multicolumn{2}{|c|}{ Bootstrap } \\
\hline & $\hat{\beta}^{O L S}$ & Sig. level & $\tilde{\beta}^{S I M}$ & Sig. level \\
\hline 1 week & $-0.0054^{*}$ & 0.090 & -0.0042 & 0.662 \\
\hline 4 weeks & $-0.0526^{* * *}$ & 0.000 & $-0.0470^{* *}$ & 0.045 \\
\hline 8 weeks & $-0.0699^{* * *}$ & 0.000 & -0.0586 & 0.145 \\
\hline 13 weeks & $-0.1158^{* * *}$ & 0.000 & $-0.0974^{*}$ & 0.058 \\
\hline 26 weeks & $-0.1746^{* * *}$ & 0.000 & $-0.1439^{*}$ & 0.052 \\
\hline \multicolumn{5}{|c|}{$07 / 1994$ to $01 / 2001$} \\
\hline \multirow[t]{2}{*}{ Reg. Horizon } & \multicolumn{2}{|c|}{ OLS } & \multicolumn{2}{|c|}{ Bootstrap } \\
\hline & $\hat{\beta}^{O L S}$ & Sig. level & $\tilde{\beta}^{S I M}$ & Sig. level \\
\hline 1 week & -0.0015 & 0.827 & -0.0004 & 0.926 \\
\hline 4 weeks & $-0.0520^{* * *}$ & 0.000 & $-0.0475^{* *}$ & 0.047 \\
\hline 8 weeks & $-0.0550^{* * *}$ & 0.009 & -0.0466 & 0.241 \\
\hline 13 weeks & $-0.0618^{* *}$ & 0.022 & -0.0481 & 0.408 \\
\hline 26 weeks & $-0.1118^{* * *}$ & 0.000 & -0.0880 & 0.252 \\
\hline
\end{tabular}

$02 / 2001$ to $06 / 2008$

\begin{tabular}{llclc} 
Reg. Horizon & \multicolumn{2}{c}{ OLS } & \multicolumn{2}{c}{ Bootstrap } \\
& $\hat{\beta}^{\text {OLS }}$ & (t-stat.) & $\tilde{\beta}^{S I M}$ & Sig. level \\
\hline 1 week & 0.0100 & 0.338 & $0.0111^{* *}$ & 0.049 \\
4 weeks & 0.0219 & 0.458 & $0.0252^{*}$ & 0.078 \\
8 weeks & 0.0200 & 0.897 & 0.0257 & 0.189 \\
13 weeks & 0.0168 & 0.308 & 0.0250 & 0.267 \\
26 weeks & $-0.0182^{* * *}$ & 0.000 & -0.0047 & 0.804 \\
\hline \hline
\end{tabular}

The table presents the $\beta$ coefficients of equation $\left(r_{t+1}+\ldots+r_{t+k}\right)=\alpha(k)+\Theta^{\prime}(k) z_{t}+$ $\beta(k) S_{t}+\epsilon_{t}^{(k)}$ obtained from OLS estimation (columns 1 and 2) and bootstrap simulations as explained in the Appendix (columns 3 and 4). Results are presented for periods of $k=1,4,8,13,26$ weeks. The control variables are listed in section $2.2 . * * *, * *$ and $*$ denote statistical significance at the $1 \%, 5 \%$ and $10 \%$ levels, respectively. 
Table 6: Estimation Results for Daily DAX Log Returns of Closing Prices

\begin{tabular}{|c|c|c|c|}
\hline Specification & $(1)$ & $(2)$ & $(3)$ \\
\hline Variable & $\begin{array}{l}\text { Coef. } \\
(\mid t-\text { stat. } \mid)\end{array}$ & $\begin{array}{l}\text { Coef. } \\
(\mid t-\text { stat. } \mid)\end{array}$ & $\begin{array}{l}\text { Coef. } \\
(\mid t-\text { stat. } \mid)\end{array}$ \\
\hline Sentix $_{t}$ & $\begin{array}{l}0.012^{* *} \\
(2.12)\end{array}$ & & \\
\hline$\Delta$ Sentix $_{t}$ & & $\begin{array}{l}0.025^{* *} \\
(2.52)\end{array}$ & \\
\hline InnoSentix $_{t}$ & & & $\begin{array}{l}0.025^{* *} \\
(2.30)\end{array}$ \\
\hline$r_{t-2, t-1}^{D A X}$ & $\begin{array}{l}-0.166^{* * *} \\
(5.98)\end{array}$ & $\begin{array}{l}-0.166^{* * *} \\
(5.83)\end{array}$ & $\begin{array}{l}-0.182^{* * *} \\
(5.99)\end{array}$ \\
\hline$r_{t-2, t-1}^{S \& P 500}$ & $\begin{array}{l}0.285^{* * *} \\
(8.91)\end{array}$ & $\begin{array}{l}0.287^{* * *} \\
(8.51)\end{array}$ & $\begin{array}{l}0.289^{* * *} \\
(8.05)\end{array}$ \\
\hline $\mathbf{1}_{\text {Mondayt }}$ & $\begin{array}{l}-0.001 \\
(1.27)\end{array}$ & $\begin{array}{l}7 \mathrm{e}-04 \\
(1.14)\end{array}$ & $\begin{array}{l}3 \mathrm{e}-04 \\
(0.51)\end{array}$ \\
\hline Const. & $\begin{array}{l}6 \mathrm{e}-04^{* *} \\
(2.33)\end{array}$ & $\begin{array}{l}6 \mathrm{e}-04^{* *} \\
(2.32)\end{array}$ & $\begin{array}{l}7 \mathrm{e}-04^{* *} \\
(2.52) \\
\end{array}$ \\
\hline $\begin{array}{l}\text { Obs. } \\
\text { Adj. } R^{2}\end{array}$ & $\begin{array}{l}1,916 \\
0.033\end{array}$ & $\begin{array}{l}1,911 \\
0.034\end{array}$ & $\begin{array}{l}1,695 \\
0.035\end{array}$ \\
\hline
\end{tabular}

The table shows the results of a $\operatorname{GARCH}(1,1)$ with mean equation $r_{t-1, t}^{D A X}=a_{0}+$ $a_{1}$ Sentiment $_{t}+a_{2} r_{t-2, t-1}^{D A X}+a_{3} r_{t-2, t-1}^{S \& P 500}+a_{4} 1_{\text {Monday }}+e_{t} . r_{t-1, t}^{D A X}$ is the return on the DAX index, $r_{t-2, t-1}^{S \& P 500}$ is the return on the S\&P 500 index, Sentiment $t_{t}$ is equal to our sentiment measure on Mondays and zero else, and $1_{\text {Mondayt }}$ is a dummy variable that is set to one on Mondays. We use three sentiment measures, the level of the Sentix index (column 1), the first difference (column 2) and the residual from a regression of the Sentix index on its lagged value and the lagged DAX and S\&P 500 returns (column 3). ***, ** and $*$ denote significance at the $1 \%, 5 \%$, and $10 \%$ level, respectively. 
Table 7: Estimation Results for Daily S\&P 500 Log Returns of Closing Prices

\begin{tabular}{|c|c|c|c|c|c|c|}
\hline \multirow[b]{2}{*}{ Specification } & \multicolumn{3}{|c|}{$07 / 1987$ to $06 / 2008$} & \multicolumn{3}{|c|}{$07 / 1987$ to $06 / 1994$} \\
\hline & $(1)$ & $(2)$ & $(3)$ & $(1)$ & $(2)$ & $(3)$ \\
\hline Variable & $\begin{array}{l}\text { Coef. } \\
(\mid t-\text { stat. } \mid)\end{array}$ & $\begin{array}{l}\text { Coef. } \\
(\mid t-\text { stat. } \mid)\end{array}$ & $\begin{array}{l}\text { Coef. } \\
(\mid t-\text { stat. } \mid)\end{array}$ & $\begin{array}{l}\text { Coef. } \\
(|t-s t a t .|)\end{array}$ & $\begin{array}{l}\text { Coef. } \\
(\mid t-\text { stat. } \mid)\end{array}$ & $\begin{array}{l}\text { Coef. } \\
(|t-s t a t .|)\end{array}$ \\
\hline$A A I I_{t}$ & $\begin{array}{l}0.000 \\
(0.17)\end{array}$ & & & $\begin{array}{l}-0.005^{* *} \\
(2.43)\end{array}$ & & \\
\hline$\Delta A A I I_{t}$ & & $\begin{array}{l}-0.001 \\
(0.77)\end{array}$ & & & $\begin{array}{l}-0.003 \\
(1.23)\end{array}$ & \\
\hline $\operatorname{InnoAAII}_{t}$ & & & $\begin{array}{l}-0.000 \\
(0.06)\end{array}$ & & & $\begin{array}{l}-0.004^{*} \\
(1.71)\end{array}$ \\
\hline$r_{t-2, t-1}^{S \& P 500}$ & $\begin{array}{l}-0.007 \\
(0.43)\end{array}$ & $\begin{array}{l}-0.007 \\
(0.48)\end{array}$ & $\begin{array}{l}-0.007 \\
(0.47)\end{array}$ & $\begin{array}{l}0.006 \\
(0.20)\end{array}$ & $\begin{array}{l}0.003 \\
(0.10)\end{array}$ & $\begin{array}{l}0.011 \\
(0.46)\end{array}$ \\
\hline $\mathbf{1}_{\text {Mondayt }}$ & $\begin{array}{l}0.000 \\
(1.15)\end{array}$ & $\begin{array}{l}0.000 \\
(1.17)\end{array}$ & $\begin{array}{l}0.000 \\
(1.40)\end{array}$ & $\begin{array}{l}0.001 \\
(1.22)\end{array}$ & $\begin{array}{l}0.001 \\
(1.33)\end{array}$ & $\begin{array}{l}0.001^{* *} \\
(2.18)\end{array}$ \\
\hline Const. & $\begin{array}{l}0.000^{* * *} \\
(3.50)\end{array}$ & $\begin{array}{l}0.000^{* * *} \\
(3.63)\end{array}$ & $\begin{array}{l}0.000^{* * *} \\
(3.06)\end{array}$ & $\begin{array}{l}0.000 \\
(1.58)\end{array}$ & $\begin{array}{l}0.000 \\
(1.28)\end{array}$ & $\begin{array}{l}0.000 \\
(0.42)\end{array}$ \\
\hline & \multicolumn{3}{|c|}{$07 / 1994$ to $01 / 2001$} & \multicolumn{3}{|c|}{$02 / 2001$ to $06 / 2008$} \\
\hline Specification & $(1)$ & $(2)$ & $(3)$ & $(1)$ & $(2)$ & $(3)$ \\
\hline Variable & $\begin{array}{l}\text { Coef. } \\
(\mid t-\text { stat. } \mid)\end{array}$ & $\begin{array}{l}\text { Coef. } \\
(|t-s t a t .|)\end{array}$ & $\begin{array}{l}\text { Coef. } \\
(\mid t-\text { stat. } \mid)\end{array}$ & $\begin{array}{l}\text { Coef. } \\
(|t-s t a t .|)\end{array}$ & $\begin{array}{l}\text { Coef. } \\
(|t-s t a t .|)\end{array}$ & $\begin{array}{l}\text { Coef. } \\
(|t-s t a t .|)\end{array}$ \\
\hline$A A I I_{t}$ & $\begin{array}{l}-0.001 \\
(0.31)\end{array}$ & & & $\begin{array}{l}0.002 \\
(0.86)\end{array}$ & & \\
\hline$\Delta A A I I_{t}$ & & $\begin{array}{l}0.002 \\
(0.54)\end{array}$ & & & $\begin{array}{l}-0.001 \\
(0.49)\end{array}$ & \\
\hline $\operatorname{Inno}_{A} A I I_{t}$ & & & $\begin{array}{l}0.001 \\
(0.24)\end{array}$ & & & $\begin{array}{l}0.001 \\
(0.30)\end{array}$ \\
\hline$r_{t-2, t-1}^{S \& P 500}$ & $\begin{array}{l}0.041 \\
(1.53)\end{array}$ & $\begin{array}{l}0.041 \\
(1.54)\end{array}$ & $\begin{array}{l}0.041 \\
(1.54)\end{array}$ & $\begin{array}{l}-0.061^{* *} \\
(2.40)\end{array}$ & $\begin{array}{l}-0.061^{* *} \\
(2.40)\end{array}$ & $\begin{array}{l}-0.061^{* *} \\
(2.39)\end{array}$ \\
\hline $\mathbf{1}_{\text {Mondayt }}$ & $\begin{array}{l}-0.000 \\
(0.62)\end{array}$ & $\begin{array}{l}-0.000 \\
(0.60)\end{array}$ & $\begin{array}{l}-0.000 \\
(0.58)\end{array}$ & $\begin{array}{l}0.000 \\
(0.58)\end{array}$ & $\begin{array}{l}0.000 \\
(0.44)\end{array}$ & $\begin{array}{l}0.000 \\
(0.44)\end{array}$ \\
\hline Const. & $\begin{array}{l}0.001^{* * *} \\
(4.04)\end{array}$ & $\begin{array}{l}0.001^{* * *} \\
(4.32)\end{array}$ & $\begin{array}{l}0.001^{* * *} \\
(4.23)\end{array}$ & $\begin{array}{l}0.000 \\
(0.98) \\
\end{array}$ & $\begin{array}{l}0.000 \\
(1.28) \\
\end{array}$ & $\begin{array}{l}0.000 \\
(1.28) \\
\end{array}$ \\
\hline
\end{tabular}

The table shows the results of a $\operatorname{GARCH}(1,1)$ with mean equation $r_{t-1, t}^{S \& P 500}=a_{0}+$ $a_{1}$ Sentiment $_{t}+a_{2} r_{t-2, t-1}^{S \& P 500}+a_{3} 1_{\text {Mondayt }}+e_{t} \cdot r_{t-1, t}^{S \& P 00}$ is the return on the S\&P 500 index, Sentiment $t_{t}$ is equal to our sentiment measure on Thursdays and zero else, and $1_{\text {Mondayt }}$ is a dummy variable that is set to one on Mondays. We use three sentiment measures, the level of the AAII index (column 1), the first difference (column 2) and the residual from a regression of the AAII index on its lagged value and the lagged S\&P 500 return (column 3 ). ${ }^{* * *},{ }^{* *}$ and ${ }^{*}$ denote significance at the $1 \%, 5 \%$, and $10 \%$ level, respectively. 
CfR working papers are available for download from www.cfr-cologne.de.

Hardcopies can be ordered from: centre for financial Research ( $C F R$ ), albertus magnus platz, 50923 koeln, Germany.

2011

\begin{tabular}{|c|c|c|}
\hline No. & Author(s) & Title \\
\hline $11-08$ & G. Cici, L.-F. Palacios & $\begin{array}{l}\text { On the Use of Options by Mutual Funds: Do They Know What } \\
\text { They Are Doing? }\end{array}$ \\
\hline $11-07$ & $\begin{array}{l}\text { V. Agarwal, G. D. Gay, } \\
\text { L. Ling }\end{array}$ & Window Dressing in Mutual Funds \\
\hline $11-06$ & $\begin{array}{l}\text { N. Hautsch, D. Hess, } \\
\text { D. Veredas }\end{array}$ & $\begin{array}{l}\text { The Impact of Macroeconomic News on Quote Adjustments, } \\
\text { Noise, and Informational Volatility }\end{array}$ \\
\hline $11-05$ & G. Cici & $\begin{array}{l}\text { The Prevalence of the Disposition Effect in Mutual Funds' } \\
\text { Trades }\end{array}$ \\
\hline 11-04 & S. Jank & Mutual Fund Flows, Expected Returns and the Real Economy \\
\hline $11-03$ & G.Fellner, E.Theissen & $\begin{array}{l}\text { Short Sale Constraints, Divergence of Opinion and Asset } \\
\text { Value: Evidence from the Laboratory }\end{array}$ \\
\hline $11-02$ & S.Jank & Are There Disadvantaged Clienteles in Mutual Funds? \\
\hline $11-01$ & V. Agarwal, C. Meneghetti & The role of Hedge Funds as Primary Lenders \\
\hline
\end{tabular}

2010

No. Author(s) Title

10-20 G. Cici, S. Gibson, Missing the Marks? Dispersion in Corporate Bond Valuations J.J. Merrick Jr. Across Mutual Funds

10-19 J. Hengelbrock, E. Theissen, Ch. Westheide

10-18 G. Cici, S. Gibson

The Performance of Corporate-Bond Mutual Funds:

Evidence Based on Security-Level Holdings

10-17 D. Hess, D. Kreutzmann,

Projected Earnings Accuracy and the Profitability of Stock

O. Pucker

Recommendations

$10-16$

S. Jank, M. Wedow

Sturm und Drang in Money Market Funds: When Money Market Funds Cease to Be Narrow

$10-15$

G. Cici, A. Kempf, A.

Caught in the Act:

Puetz

How Hedge Funds Manipulate their Equity Positions

$10-14$

J. Grammig, S. Jank

Creative Destruction and Asset Prices 
$10-13$

S. Jank, M. Wedow

10-12 S. Artmann, P. Finter,

A. Kempf, S. Koch,

E. Theissen

10-11

10-10

M. Chesney, A. Kempf

S. Frey, P. Herbst

10-09 V. Agarwal, W. Jiang, Y. Tang, B. Yang

10-08 V. Agarwal, V. Fos, W. Jiang

10-07 V. Agarwal, G. Bakshi, J. Huij

10-06 J. Grammig, F. J. Peter

10-05 K. Drachter, A. Kempf

10-04 J. Fang, A. Kempf, M. Trapp

10-03 P. Finter, A. NiessenRuenzi, S. Ruenzi

10-02 D. Hunter, E. Kandel,

S. Kandel, R. Wermers

10-01 S. Artmann, P. Finter, A. Kempf
Purchase and Redemption Decisions of Mutual Fund Investors and the Role of Fund Families

The Cross-Section of German Stock Returns:

New Data and New Evidence

The Value of Tradeability

The Influence of Buy-side Analysts on Mutual Fund Trading

Uncovering Hedge Fund Skill from the Portfolio Holdings They Hide

Inferring Reporting Biases in Hedge Fund Databases from Hedge Fund Equity Holdings

Do Higher-Moment Equity Risks Explain Hedge Fund Returns?

Tell-Tale Tails

Höhe, Struktur und Determinanten der ManagervergütungEine Analyse der Fondsbranche in Deutschland

Fund Manager Allocation

The Impact of Investor Sentiment on the German Stock Market

Endogenous Benchmarks

Determinants of Expected Stock Returns: Large Sample Evidence from the German Market

2009

\begin{tabular}{|c|c|c|}
\hline No. & Author(s) & Title \\
\hline $09-17$ & E. Theissen & $\begin{array}{l}\text { Price Discovery in Spot and Futures Markets: } \\
\text { A Reconsideration }\end{array}$ \\
\hline $09-16$ & M. Trapp & $\begin{array}{l}\text { Trading the Bond-CDS Basis - The Role of Credit Risk } \\
\text { and Liquidity }\end{array}$ \\
\hline $09-14$ & $\begin{array}{l}\text { A. Kempf, O. Korn, } \\
\text { M. Uhrig-Homburg }\end{array}$ & The Term Structure of Illiquidity Premia \\
\hline $09-13$ & W. Bühler, M. Trapp & $\begin{array}{l}\text { Time-Varying Credit Risk and Liquidity Premia in Bond and } \\
\text { CDS Markets }\end{array}$ \\
\hline $09-12$ & W. Bühler, M. Trapp & $\begin{array}{l}\text { Explaining the Bond-CDS Basis - The Role of Credit Risk and } \\
\text { Liquidity }\end{array}$ \\
\hline $09-11$ & $\begin{array}{l}\text { S. J. Taylor, P. K. Yadav, } \\
\text { Y. Zhang }\end{array}$ & Cross-sectional analysis of risk-neutral skewness \\
\hline $09-10$ & $\begin{array}{l}\text { A. Kempf, C. Merkle, } \\
\text { A. Niessen }\end{array}$ & $\begin{array}{l}\text { Low Risk and High Return - How Emotions Shape } \\
\text { Expectations on the Stock Market }\end{array}$ \\
\hline 09-09 & $\begin{array}{l}\text { V. Fotak, V. Raman, } \\
\text { P. K. Yadav }\end{array}$ & Naked Short Selling: The Emperor's New Clothes? \\
\hline $09-08$ & $\begin{array}{l}\text { F. Bardong, S.M. Bartram, } \\
\text { P.K. Yadav }\end{array}$ & $\begin{array}{l}\text { Informed Trading, Information Asymmetry and Pricing of } \\
\text { Information Risk: Empirical Evidence from the NYSE }\end{array}$ \\
\hline
\end{tabular}


S. J. Taylor , P. K. Yadav, The information content of implied volatilities and model-free Y. Zhang volatility expectations: Evidence from options written on individual stocks
09-06 S. Frey, P. Sandas
The Impact of Iceberg Orders in Limit Order Books
09-05 H. Beltran-Lopez, P. Giot, J. Grammig
09-04
J. Fang, S. Ruenzi
Rapid Trading bei deutschen Aktienfonds:
Evidenz aus einer großen deutschen Fondsgesellschaft
09-03 A. Banegas, B. Gillen,
A. Timmermann,
R. Wermers
09-02 J. Grammig, A. Schrimpf, M. Schuppli
The Performance of European Equity Mutual Funds
09-01
O. Korn, P. Koziol Long-Horizon Consumption Risk and the Cross-Section
of Returns: New Tests and International Evidence
The Term Structure of Currency Hedge Ratios

2008

\begin{tabular}{|c|c|c|}
\hline No. & Author(s) & Title \\
\hline 08-12 & $\begin{array}{l}\text { U. Bonenkamp, } \\
\text { C. Homburg, A. Kempf }\end{array}$ & Fundamental Information in Technical Trading Strategies \\
\hline 08-11 & O. Korn & Risk Management with Default-risky Forwards \\
\hline $08-10$ & J. Grammig, F.J. Peter & $\begin{array}{l}\text { International Price Discovery in the Presence } \\
\text { of Market Microstructure Effects }\end{array}$ \\
\hline 08-09 & C. M. Kuhnen, A. Niessen & Public Opinion and Executive Compensation \\
\hline $08-08$ & A. Pütz, S. Ruenzi & $\begin{array}{l}\text { Overconfidence among Professional Investors: Evidence from } \\
\text { Mutual Fund Managers }\end{array}$ \\
\hline $08-07$ & P. Osthoff & What matters to SRI investors? \\
\hline 08-06 & A. Betzer, E. Theissen & $\begin{array}{l}\text { Sooner Or Later: Delays in Trade Reporting by Corporate } \\
\text { Insiders }\end{array}$ \\
\hline 08-05 & P. Linge, E. Theissen & $\begin{array}{l}\text { Determinanten der Aktionärspräsenz auf } \\
\text { Hauptversammlungen deutscher Aktiengesellschaften }\end{array}$ \\
\hline 08-04 & $\begin{array}{l}\text { N. Hautsch, D. Hess, } \\
\text { C. Müller }\end{array}$ & Price Adjustment to News with Uncertain Precision \\
\hline 08-03 & $\begin{array}{l}\text { D. Hess, H. Huang, } \\
\text { A. Niessen }\end{array}$ & $\begin{array}{l}\text { How Do Commodity Futures Respond to Macroeconomic } \\
\text { News? }\end{array}$ \\
\hline 08-02 & $\begin{array}{l}\text { R. Chakrabarti, } \\
\text { W. Megginson, P. Yadav }\end{array}$ & Corporate Governance in India \\
\hline 08-01 & C. Andres, E. Theissen & $\begin{array}{l}\text { Setting a Fox to Keep the Geese - Does the Comply-or-Explain } \\
\text { Principle Work? }\end{array}$ \\
\hline
\end{tabular}

No. Author(s) Title

07-16 M. Bär, A. Niessen, 
M. Kasch-Haroutounian,

E. Theissen

07-09 V. Agarwal, N. D. Daniel, N. Y. Naik

07-08 N. C. Brown, K. D. Wei, R. Wermers

07-07 A. Betzer, E. Theissen

07-06 V. Agarwal, L. Wang

07-05 J. Grammig, A. Schrimpf

07-04 V. Agarwal, N.M. Boyson, N.Y. Naik

07-03 D. Hess, A. Niessen

07-02 A. Kempf, S. Ruenzi, T. Thiele

07-01 M. Hagemeister, A. Kempf
Political Connectedness and Firm Performance: Evidence From Germany

Hedging Price Risk when Payment Dates are Uncertain

SRI Funds: Nomen est Omen

Time and Price Impact of a Trade: A Structural Approach

On the Relative Performance of Multi-Strategy and Funds of Hedge Funds

Competition Between Exchanges: Euronext versus Xetra

Do hedge funds manage their reported returns?

Analyst Recommendations, Mutual Fund Herding, and Overreaction in Stock Prices

Insider Trading and Corporate Governance:

The Case of Germany

Transaction Costs and Value Premium

Asset Pricing with a Reference Level of Consumption:

New Evidence from the Cross-Section of Stock Returns

Hedge Funds for retail investors?

An examination of hedged mutual funds

The Early News Catches the Attention:

On the Relative Price Impact of Similar Economic Indicators

Employment Risk, Compensation Incentives and Managerial Risk Taking - Evidence from the Mutual Fund Industry -

CAPM und erwartete Renditen: Eine Untersuchung auf Basis der Erwartung von Marktteilnehmern

2006

\begin{tabular}{ll} 
No. & Author(s) \\
\hline
\end{tabular}

06-13 S. Čeljo-Hörhager, A. Niessen

06-12 R. Wermers, Y. Wu, J. Zechner

06-11 U. v. Lilienfeld-Toal, S. Ruenzi

06-10 A. Kempf, P. Osthoff

06-09 R. Wermers, T. Yao, J. Zhao

06-08 M. Hoffmann, B. Kempa

06-07 K. Drachter, A. Kempf, M. Wagner

06-06 J.P. Krahnen, F.A. Schmid, E. Theissen

06-05
How do Self-fulfilling Prophecies affect Financial Ratings? - An experimental study

Portfolio Performance, Discount Dynamics, and the Turnover of Closed-End Fund Managers

Why Managers Hold Shares of Their Firm: An Empirical Analysis

The Effect of Socially Responsible Investing on Portfolio Performance

The Investment Value of Mutual Fund Portfolio Disclosure

The Poole Analysis in the New Open Economy Macroeconomic Framework

Decision Processes in German Mutual Fund Companies: Evidence from a Telephone Survey

Investment Performance and Market Share: A Study of the German Mutual Fund Industry

On the Usability of Synthetic Measures of Mutual Fund Net- 
Flows

\begin{tabular}{|c|c|c|}
\hline 06-04 & A. Kempf, D. Mayston & Liquidity Commonality Beyond Best Prices \\
\hline 06-03 & O. Korn, C. Koziol & Bond Portfolio Optimization: A Risk-Return Approach \\
\hline 06-02 & $\begin{array}{l}\text { O. Scaillet, L. Barras, R. } \\
\text { Wermers }\end{array}$ & $\begin{array}{l}\text { False Discoveries in Mutual Fund Performance: Measuring } \\
\text { Luck in Estimated Alphas }\end{array}$ \\
\hline 06-01 & A. Niessen, S. Ruenzi & Sex Matters: Gender Differences in a Professional Setting \\
\hline
\end{tabular}

2005

No. Author(s) Title

05-16 E. Theissen

An Analysis of Private Investors' Stock Market Return Forecasts

05-15 T. Foucault, S. Moinas,

Does Anonymity Matter in Electronic Limit Order Markets

E. Theissen

05-14 R. Kosowski,

A. Timmermann,

R. Wermers, H. White

05-13 D. Avramov, R. Wermers

Can Mutual Fund „Stars“ Really Pick Stocks?

New Evidence from a Bootstrap Analysis

05-12 K. Griese, A. Kempf

Investing in Mutual Funds when Returns are Predictable

05-11 S. Ber, A. Kempf,

S. Ruenzi

05-10 M. Bär, A. Kempf,

S. Ruenzi

05-09 M. Hoffmann

05-08 S. Ruenzi

05-07 A. Kempf, S. Ruenzi

05-06 J. Grammig,

E. Theissen

05-05 H. Beltran,

J. Grammig,

A.J. Menkveld

05-04 M. Hoffmann

05-03 M. Hoffmann

05-02 A. Kempf, C. Memmel

Liquiditätsdynamik am deutschen Aktienmarkt

Determinanten der Mittelzuflüsse bei deutschen Aktienfonds

Is a Team Different From the Sum of Its Parts?

Evidence from Mutual Fund Managers

Saving, Investment and the Net Foreign Asset Position

Mutual Fund Growth in Standard and Specialist Market Segments

Status Quo Bias and the Number of Alternatives

- An Empirical Illustration from the Mutual Fund Industry -

Is Best Really Better? Internalization of Orders in an Open Limit Order Book

Understanding the Limit Order Book: Conditioning on Trade Informativeness

Compensating Wages under different Exchange rate Regimes

Fixed versus Flexible Exchange Rates: Evidence from Developing Countries

On the Estimation of the Global Minimum Variance Portfolio

05-01 S. Frey, J. Grammig

Liquidity supply and adverse selection in a pure limit order book market

2004

No.

Author(s)

Title

04-10

N. Hautsch, D. Hess

Bayesian Learning in Financial Markets - Testing for the Relevance of Information Precision in Price Discovery

04-09

A. Kempf,

Portfolio Disclosure, Portfolio Selection and Mutual Fund 
K. Kreuzberg

04-08 N.F. Carline, S.C. Linn, P.K. Yadav

04-07 J.J. Merrick, Jr., N.Y. Naik, P.K. Yadav

04-06 N.Y. Naik, P.K. Yadav

04-05 A. Kempf, S. Ruenzi

04-04 V. Agarwal,

N.D. Daniel, N.Y. Naik

04-03 V. Agarwal, W.H. Fung, J.C. Loon, N.Y. Naik

04-02 A. Kempf, S. Ruenzi

04-01 I. Chowdhury, M. Hoffmann, A. Schabert
Performance Evaluation

Operating performance changes associated with corporate mergers and the role of corporate governance

Strategic Trading Behavior and Price Distortion in a Manipulated Market: Anatomy of a Squeeze

Trading Costs of Public Investors with Obligatory and Voluntary Market-Making: Evidence from Market Reforms

Family Matters: Rankings Within Fund Families and Fund Inflows

Role of Managerial Incentives and Discretion in Hedge Fund Performance

Risk and Return in Convertible Arbitrage:

Evidence from the Convertible Bond Market

Tournaments in Mutual Fund Families

Inflation Dynamics and the Cost Channel of Monetary

Transmission 
